Article

\title{
An Integrated Sustainable Construction Project's Critical Success Factors (ISCSFs)
}

\author{
Ahmed S. El Touny *, Ahmed H. Ibrahim and Hossam H. Mohamed \\ Construction Engineering Department, Faculty of Engineering, Zagazig University, Zagazig 44519, Egypt; \\ mekky1999@gmail.com (A.H.I.); hosny_hosm64@yahoo.com (H.H.M.) \\ * Correspondence: ah.eltouny@gmail.com
}

Citation: El Touny, A.S.;

Ibrahim, A.H.; Mohamed, H.H. An Integrated Sustainable Construction Project's Critical Success Factors (ISCSFs). Sustainability 2021, 13, 8629. https://doi.org/10.3390/su13158629

Academic Editor: Sunkuk Kim

Received: 1 July 2021

Accepted: 31 July 2021

Published: 2 August 2021

Publisher's Note: MDPI stays neutral with regard to jurisdictional claims in published maps and institutional affiliations.

Copyright: (c) 2021 by the authors. Licensee MDPI, Basel, Switzerland. This article is an open access article distributed under the terms and conditions of the Creative Commons Attribution (CC BY) license (https:// creativecommons.org/licenses/by/ $4.0 /)$.

\begin{abstract}
A construction project is a dynamic and complex process that involves the identification and accurate fulfillment of the predetermined needs and requirements of the clients by the project team. There are many challenges and constraints that prevent the achievement of these predetermined and various requirements effectively and successfully, so the project team must face and overcome these challenges by identifying all the factors that help the project's success. However, it is still unclear how to measure success for Egyptian construction projects. Despite the fact that several lists of literaturebased factors have been compiled, the individual factors appear to be tabulated rather than grouped according to some criteria to aid in the analysis of their interactions and potential consequences. As such, the objective presented in this paper was to identify and prioritize integrated sustainable critical success factors (ISCSFs) that influence the performance of Egyptian construction projects to ensure successful construction projects. Critical success factors were identified and grouped into 2 major categories-(1) internal related factors and (2) external related factors-and 10 subcategories(1) company-related factors; (2) project-related factors; (3) project management related factors; (4) resource/procurement-related factors (labors, materials, equipment and subcontractors); (5) human capital-related factors; (6) support-related factors (financial, human resources, security and legal and administration); (7) stakeholder-related factors (clients, consultants, project managers and end-users); (8) innovation, learning and growth-related factors; (9) country-related factors; and (10) industryrelated factors in three distinct stages. In total, 140 factors were gathered from the literature review in the first stage. In the second stage, a brainstorming session was held in order to reduce the number of those factors and focus on the most important ones that influence project success; thus, 100 factors were identified, filtered and developed. In the third stage, a questionnaire was created based on the significant factors identified. As a result, the 40 most important factors influencing the success of performance of construction projects have been identified, which are integrated between all factors (internal and external) and take into account the three pillars of sustainability (economic, social and environmental) as a decision-making tool to evaluate and improve project performance.
\end{abstract}

Keywords: construction project; integrated sustainable critical success factors (ISCSFs); performance; sustainability

\section{Introduction}

Since the 1950s, most project management research has focused on project scheduling issues, with the hope that better scheduling techniques would lead to better management and, as a result, successful project completion [1]. The success of a project is at the heart of project management. The degree of project success is influenced by a number of factors. As a result, project success is a top priority for all project stakeholders. In line with Cooke [2], it has long been acknowledged that project success can take two forms. The project's success is said to be determined by the judgments associated with the project outputs, while the project management's success is said to be determined by the successful implementation of the project. A well-planned project may fail to deliver the desired results, while a poorly managed project may succeed at a high cost [3]. 
Critical success factors (CSFs) vary according to the relevant research and procedures, but they are all necessary for achieving a specific strategic goal. The quantifiable metrics for CSFs are performance indicators. Only a few studies have been conducted to spot, evaluate, clarify or analyze these so-called critical success factors. Early studies in this area tended to focus on the reasons for a project's failure rather than its success.

Construction is a business that is fraught with risk, and therefore the possibility of failure is usually present; thus, construction companies should consider factors that may have an immediate impact on their success in the performance of a construction project [4]. Due to increasing uncertainties in many areas, such as technology, budgets and development processes, the development industry is dynamic. Construction projects are becoming more complicated and difficult to complete. A construction project is completed as a result of a series of planned and unplanned interactions and events that take place over the lifetime of the project, with changing processes and participants in an ever-changing environment. On the other hand, the concept of project success continues to be a source of difficulty for construction professionals [5].

The construction sector still faces challenges due to time delays, excessive costs, poor quality and safety. It is important to understand a project's performance and the relationship between results and initial objectives to overcome these challenges. A project manager cannot control or improve performance if they cannot evaluate and measure a project's success. Furthermore, despite the fact that several lists of factors from the literature have been generated, and because the way to measure success for Egyptian construction projects is still unclear, researchers appear to tabulate the individual factors rather than group them according to some criteria to aid in the analysis of their interactions and possible consequences. As a result, there is a continuing need to identify and determine the factors that influence the success of construction projects. As a result, the goal of this research is to identify integrated and sustainable critical success factors (ISCSFs) for construction projects that influence project performance in Egypt in order to ensure project success.

\section{Previous Studies}

Rubin and Seelig [6] were the first to introduce failure and success factors. They looked at technical performance as a criterion for success. The conclusion is that the project manager's previous experience has little impact on the project's performance, whereas the size of the pre-managed project has an impact on the manager's performance.

Avots [7] identified the causes of a project's failure and concluded that the project manager's poor selection, the project's unplanned termination and the lack of support from top management were the primary causes of failure.

Hughes [8] considered the factors that affected a project's performance. He came to the conclusion that projects failed due to poor basic management principles, such as a lack of specialization in management systems, rewards for bad behavior and failure to communicate goals. "Project mission", "senior management support" and "project planning" are among the strategic factors, while "customer advice" and "employee selection and training" are among the tactical factors.

Pinto and Prescott [9] presented the primary efforts to categorize the critical factors. They classify the factors as tactical or strategic. These two categories influence the performance of the project at different stages of implementation. Finally, Pinto and Prescott [9] considered the relative importance of each category (tactical versus strategic) on the project's life cycle in a similar study. According to the measure of success used, the relative importance of success factors varies throughout the project lifecycle. When using external success measures, tactical factors take precedence throughout the project lifecycle.

Belassie and Tukel [1] proposed a framework for identifying a project's critical success factors. They grouped CSFs into four areas: project-related factors, team members and project manager-related factors, organization-related factors and external environmentrelated factors. 
Baker et al. [10] proposed that, instead of using time, cost and performance as indicators of project success, the measure should be perceived performance.

A hierarchical model for a construction project's success was proposed by Chua et al. [11]. The most important measures that contribute to the "construction project success" goal in this model are the schedule, budget and quality objectives.

Lim and Mohamed [12] formulated an accurate measurement of project success: point of view, cost of completion, completion time, quality of completion, performance of completion, integrity of completion, overall views, time required, satisfaction with achievement, usefulness of accomplishment and process of accomplishment.

According to Sadeh et al. [13], project success is divided into four dimensions: meeting project objectives, which applies to the client's contract; benefit to the end-user, which refers to the customer's enjoyment of the final products and thus the pleasure of the developing organization; and the benefit gained by the organization. The benefits impact the state's technological infrastructure and firms participating in the development process as a result of the project's implementation.

Atkinson [14] divided success factors into delivery and post-delivery phases and provided a "square path" to understanding success factors: the Iron Triangle, system, (organizational) benefits and utility (community of stakeholders). The "Iron Triangle" has three criteria: time, cost and quality (for the delivery stage). The knowledge system includes criteria such as maintainability, validity, reliability and use of knowledge quality; (organizational) benefits: increasing effectiveness, efficiency, profits, strategic objectives, organizational learning and reducing waste; and (stakeholder community) benefits: social and environmental impact, satisfied users and personal development. Contractor profits, professional development, the content project team, capital suppliers and the economic impact on the surrounding community are all factors to consider.

Saqib et al. [5] investigated Pakistani construction projects and were able to identify 77 workers in 7 different categories, as well as 10 critical success factors in Pakistani construction projects.

Patanakul and Milosevic [15] divided their success criteria into three categories: (1) organizational criteria such as resource productivity and organizational learning; (2) project criteria such as customer satisfaction and time to completion; and (3) organizational criteria such as personal perspective, personal growth and private satisfaction.

Khosravi and Afshari [16] developed a model for assessing the success of construction projects with two main goals in mind: to create a project success index for each completed project and compare it to other projects and establish a baseline for future improvements in construction success and project implementation. The model output could be a project success index that is calculated to support the five criteria for project success. The criteria for calculating the project success index are as follows: project success index, project cost, project time, project quality, project health, safety, environmental performance and project customer satisfaction.

Müller and Jugdev [3] observed that success is defined and measured in a variety of ways. CSFs differ depending on the life cycle stage, project type, industry, nationality, individuals and organizations.

Gudiene et al. [17] classified CSFs for construction projects in Lithuania using AHP.

Ihuah et al. [18] identified 22 critical project management success factors (CPMSF) that are necessary for the delivery or provision of sustainable social (public) housing estates in Nigeria.

For public construction projects in Ghana, Osei-Kyei and Chan [19] implemented a public-private partnership (PPP) policy.

Molwus et al. [20] focused on the interrelationship between stakeholders and project success. Stakeholder dynamics (SD) and stakeholder engagement/empowerment (SE) were studied. They discovered that the role of stakeholders is critical to a project's success. 
Banihashemi et al. [21] investigated CSFs and integrated these factors with three bottom-line sustainability factors (economic, social and environmental). Some factors, such as the competence and experience of project managers, were also included.

Tripathi and Jha [22] evaluated and characterized success patterns within the industry by analyzing fuzzy factors and methods. To assess an organization's effectiveness, Tripathi and Jha [23] used structural equation modeling (SEM) to test the link between six success factors and five performance factors.

Maghsoodi and Khalilzadeh [24] prepared a questionnaire considering time, cost, quality and safety to assess CSFs.

Gunduz and Almuajebh [25] prepared and prioritized a list of 40 CSFs according to seven categories in the construction industry.

Papulová et al. [26] developed recommendations and a list of CSFs for each phase of the PMS implementation process, taking into account the unique characteristics and needs of SMEs.

According to Liu et al. [27], in a sustainable business environment for emerging countries, the development of the construction industry environment within the framework of sustainable construction (SC) is possible.

The framework proposed by Xiahou et al. [28] using the FAHP method is viable for conducting a social performance evaluation of construction projects, in which more factors should be taken into account to improve social performance, reduce negative social impacts and contribute to the social sustainability of construction projects.

According to previous literature, despite numerous attempts by various researchers to determine CSFs for construction projects, the concept of CSFs has remained ill-defined. Although several lists of factors have been compiled, they appear to tabulate the individual factors rather than group them according to some criteria.

The majority of these studies were context-specific, with their implementation and implications limited to the countries and operating environments in which they were conducted. There is a lack of effort made to contextualize the findings in local contexts where the structure, culture and maturity of the organizations involved differ. Because each industry has its own criteria for project success, it is still unclear how to measure project success in the Egyptian construction industry. As a result, there is an ongoing need to identify and determine the factors that influence the success of construction projects in Egypt in an integrated and sustainable manner.

The findings of this work are expected to fill research gaps in the construction industry and provide useful information and practical advice for project success.

Based on the literature, several factors and their groups that are thought to have an immediate effect on project success were determined and supported by several references, as shown in Table 1.

Table 1. Literature regarding the grouping of CSFs in projects (summary).

\begin{tabular}{|c|c|c|}
\hline Researcher & Year & Grouping the CSFs in Projects \\
\hline Avots [7] & 1969 & $\begin{array}{l}\text { - Identified the causes of the project's failure and concluded that the project } \\
\text { manager's poor selection, the project's unplanned termination and the absence } \\
\text { of top management's support were the primary causes of the failure. }\end{array}$ \\
\hline Hughes [8] & 1986 & $\begin{array}{l}\text { - Goals must be communicated and basic managerial principles must be } \\
\text { followed. }\end{array}$ \\
\hline Pinto and Prescott [9] & 1990 & - $\quad$ Factors were classified as strategic or tactical. \\
\hline
\end{tabular}


Table 1. Cont.

\begin{tabular}{|c|c|c|}
\hline Researcher & Year & Grouping the CSFs in Projects \\
\hline Belassi and Tukel [1] & 1996 & $\begin{array}{l}\text { - } \quad \text { Factors that are dependent on the project. } \\
\text { - } \quad \text { Fependent factors include team members and the project manager. } \\
\text { - } \quad \text { Factors that are influenced by the organization's structure. } \\
\text { - }\end{array}$ \\
\hline Chua et al. [11] & 1999 & - $\quad$ Budget, schedule and quality are all important considerations. \\
\hline Lim and Mohamed [12] & 1999 & $\begin{array}{l}\text { - Completion cost, time, quality, performance and safety are all considered from } \\
\text { a micro perspective. }\end{array}$ \\
\hline
\end{tabular}

- Meeting design objectives, which pertains to a contract signed by the customer.

- The benefit to the end-user, which refers to the advantages that end products provide to customers.

Sadeh et al. [13]

2000

- The benefit that the developing organization receives as a result of the project's completion is referred to as the benefit to the developing organization.

- Benefit for the country's technological infrastructure as well as firms involved in the development process.

- The Iron Triangle (time, cost and quality), the information system, the Atkinson [14]

- In total, 77 factors were divided into seven groups, resulting in the prioritization of 10 CSFs in Pakistani construction projects.

- Project management, troubleshooting, subcontractor experience and the contractor's cash flow are all factors to consider.

- Organizational criteria include resource productivity and organizational learning.

Patanakul and Milosevic [15]

- Time-to-market and customer satisfaction are two project-related criteria.

- $\quad$ From a personal standpoint, the following criteria apply: personal growth and satisfaction.

- $\quad$ The output of the developed model could be a project success index that is calculated based on five project success criteria.

Khosravi and Afshari [16]

2011

- The formula for calculating the project success index includes project success index, project cost, project time, project quality, project health, safety, environmental performance and project customer satisfaction.

\begin{tabular}{cccl}
\hline Müller and Jugdev [3] & 2012 & $\bullet$ & $\begin{array}{l}\text { Different CSFs exist for different project types, life cycle phases, nationalities, } \\
\text { individuals, industries and organizations. }\end{array}$ \\
\hline Gudiene et al. [17] & 2014 & $\bullet$ & Factors pertaining to people, projects and the environment \\
\hline Ihuah et al. [18] & 2014 & $\bullet$ & $\begin{array}{l}\text { A competent project team has a project manager/leader authority, realistic } \\
\text { project time and cost estimates and project problem-solving abilities. }\end{array}$ \\
\hline Osei-Kyei and Chan [19] & 2017 & $\bullet$ & $\begin{array}{l}\text { Important factors to consider include government commitment and support, } \\
\text { strong community support and relationships, transparency and constant } \\
\text { communication, project profitability and a capable private partner. }\end{array}$ \\
\hline Molwus et al. [20] & - $\begin{array}{l}\text { Stakeholder characteristics include stakeholder project characteristics, } \\
\text { stakeholder analysis, stakeholder dynamics and stakeholder } \\
\text { engagement/empowerment. }\end{array}$ \\
\hline
\end{tabular}


Table 1. Cont.

\begin{tabular}{|c|c|c|}
\hline Researcher & Year & Grouping the CSFs in Projects \\
\hline Banihashemi et al. [21] & 2017 & $\begin{array}{l}\text { - Experience and competence of project managers, commitment to high-quality } \\
\text { workmanship and involvement of stakeholders, as well as innovative practices. }\end{array}$ \\
\hline Tripathi and Jha [22] & 2018 & $\begin{array}{l}\text { - According to the findings, the most important factor is the project, while the } \\
\text { least important factor is a favorable market and marketing team. } \\
\text { The availability of qualified personnel is the most important success attribute, } \\
\text { while the health and safety management plan is the least important. }\end{array}$ \\
\hline Tripathi and Jha [23] & 2018 & $\begin{array}{l}\text { - The most important factor is top management competence, followed by } \\
\text { "experience and performance". }\end{array}$ \\
\hline Maghsoodi and Khalilzadeh [24] & 2018 & $\begin{array}{l}\text { - The most important factor is top management competence, followed by } \\
\text { "experience and performance". }\end{array}$ \\
\hline Gunduz and Almuajebh [25] & 2020 & $\begin{array}{l}\text { - Company-related factors, project-related factors, project management factors, } \\
\text { client-related factors, design team-related factors, contractor-related factors } \\
\text { and project manager-related factors were compiled and prioritized into seven } \\
\text { categories. }\end{array}$ \\
\hline
\end{tabular}

\section{Methodology}

The development of the ISCSFs consists of five stages, as shown in Figure 1:

- The first stage is the investigation of previous studies (literature review), reviewing CSFs and concentrating on construction projects;

- The second stage is filtering and minimizing success factors with a brainstorming session and then a questionnaire;

- The third stage is data collection and analysis;

- The fourth stage is the determination of critical success factors (ISCSFs);

- The fifth stage is the presentation of the conclusion.

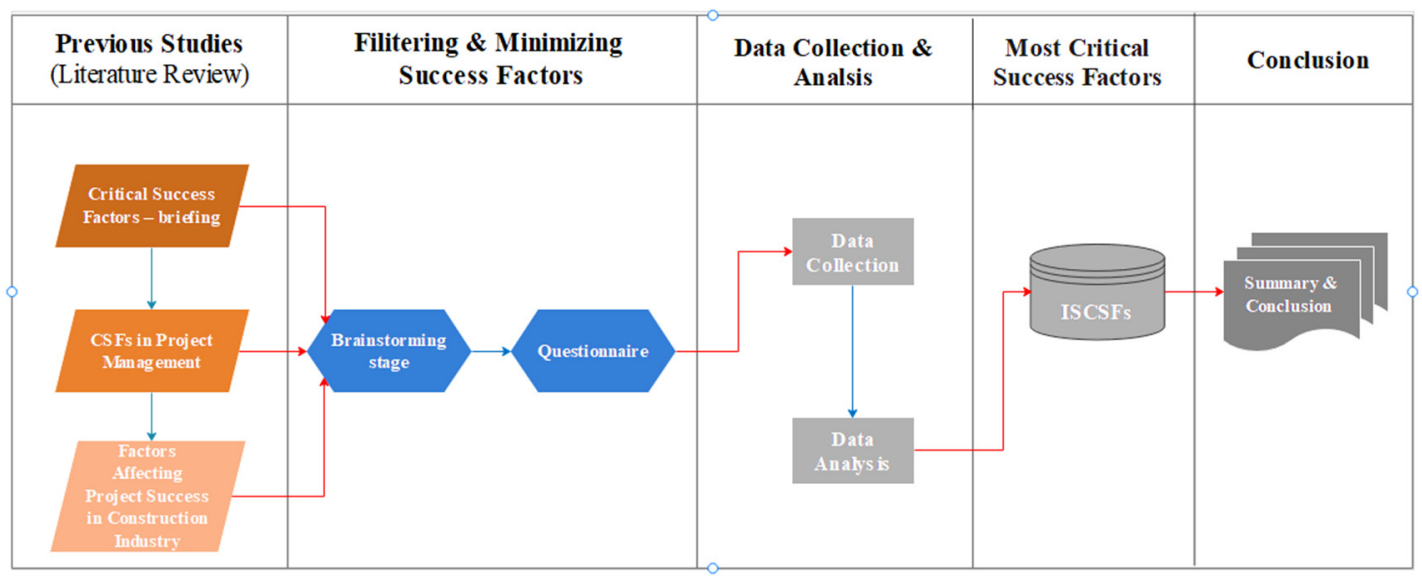

Figure 1. Research methodology.

\section{Development of a Construction Project's Integrated Sustainable Critical Success Factors (ISCSFs)}

\subsection{Factors Affecting Project Success in the Construction Industry}

Based on previous studies, several factors and their groups that were thought to have an immediate effect on project success were determined. These factors and their groups were filtered. In total, 140 factors were collected from the previous literature review and assigned into 2 major categories-internal related factors and external related factors-and 
10 subcategories—company-related factors; project-related factors; project managementrelated factors; resource/ procurement-related factors (labors, materials, equipment and subcontractors); human capital-related factors, support-related factors (financial, human resources, security and legal and administration); stakeholder-related factors (clients, consultants, project managers and end-users); innovation, learning and growth-related factors; country-related factors; and industry-related factors, as shown in Figure 2 and Table 2.

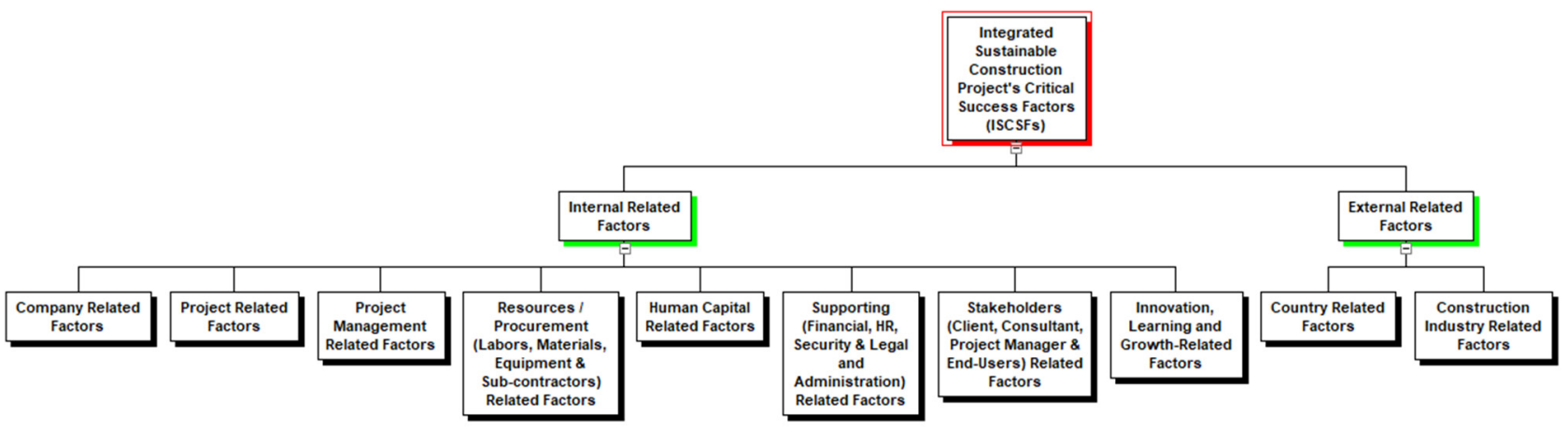

Figure 2. Hierarchy of project success categories and subcategories.

Table 2. Summarized list of 140 factors affecting project success from the literature.

\begin{tabular}{|c|c|c|c|}
\hline Categories & Subcategories & Success Factors & References \\
\hline & \multirow{13}{*}{$\begin{array}{l}\text { Company-Related } \\
\text { Factors }\end{array}$} & $\begin{array}{l}\text { Availability of appropriate standards for leadership, organization, } \\
\text { structural and cultural aspects }\end{array}$ & [29] \\
\hline & & $\begin{array}{l}\text { Availability of appropriate standards for tools, processes and } \\
\text { metrics }\end{array}$ & [29] \\
\hline & & $\begin{array}{l}\text { Availability of a standardized information system for project } \\
\text { management }\end{array}$ & [29] \\
\hline & & Existence of appropriate ethical standards for projects & [30] \\
\hline & & $\begin{array}{l}\text { Appropriate clarification of the responsibility for problems } \\
\text { related to the project }\end{array}$ & [31] \\
\hline & & Company characteristics & [17] \\
\hline & & $\begin{array}{l}\text { The due separation between daily work activities and strategic } \\
\text { activities }\end{array}$ & [32] \\
\hline & & Delegation of authority and responsibility & [17] \\
\hline & & Standardization of decision-making process & [33] \\
\hline \multirow{8}{*}{$\begin{array}{l}\text { Internal Related } \\
\text { Factors }\end{array}$} & & Company-wide acceptance (contractor) & [17] \\
\hline & & Contractor's competence and experience & [17] \\
\hline & & Economic and financial situation & [17] \\
\hline & & Top management commitment and support & [17] \\
\hline & \multirow[b]{4}{*}{ Project-Related Factors } & Project type (new, existing, maintenance) (public-private) & [17] \\
\hline & & Project value & [17] \\
\hline & & $\begin{array}{l}\text { Availability of project documents (drawings, specifications, } \\
\text { contract and bill of quantities) }\end{array}$ & [34] \\
\hline & & Well-defined scope of work and project constraints & {$[33,34]$} \\
\hline
\end{tabular}


Table 2. Cont.

\begin{tabular}{|c|c|c|c|}
\hline Categories & Subcategories & Success Factors & References \\
\hline & & A clear description of project requirements, goals and objectives & {$[33,35,36]$} \\
\hline & & Complexity and uniqueness of the project & [34] \\
\hline & & The urgency of the project outcome & [34] \\
\hline & & Density of project & [34] \\
\hline & & A clear and detailed written contract & [34] \\
\hline & & Legal and contractual risk management & [34] \\
\hline & \multirow{33}{*}{$\begin{array}{c}\text { Project } \\
\text { Management-Related } \\
\text { Factors }\end{array}$} & Achieving profitability & [17] \\
\hline & & Cash flow (in, out and net) (minimizing deficit) & [34] \\
\hline & & Achieving work volume (planned/actual) & [34] \\
\hline & & Effective project organization structure & [34] \\
\hline & & Achieving productivity & [34] \\
\hline & & Construction methods and constructability & [17] \\
\hline & & Effective project time planning, monitoring and control & [34] \\
\hline & & Effective project cost planning, monitoring and control & [34] \\
\hline & & Effective project risk planning, monitoring and control & [34] \\
\hline & & Effective project quality planning, monitoring and control & [34] \\
\hline & & $\begin{array}{l}\text { Effective project health and safety planning, monitoring and } \\
\text { control }\end{array}$ & [17] \\
\hline & & Effective project resource planning, monitoring and control & [37] \\
\hline & & Effective troubleshooting and feedback & {$[36,38]$} \\
\hline & & Effective contract management & [34] \\
\hline & & Effective management of project changes and variations & {$[33,39-44]$} \\
\hline & & Effective collaboration and communication & {$[33,45]$} \\
\hline & & Effective project performance management system & [17] \\
\hline & & Effective and timely conflict resolution & [34] \\
\hline & & Decision-making effectiveness & [25] \\
\hline & & Consider both opportunities and threats & [31] \\
\hline & & Obstacles and initiatives & [34] \\
\hline & & Implementation of effective project & [34] \\
\hline & & Good communication and information sharing & {$[33,45]$} \\
\hline & & Supervision of subcontractors' works & [34] \\
\hline & & Site management and supervision & [34] \\
\hline & & Adequate budget availability & {$[33,46]$} \\
\hline & & Budget updates & [33] \\
\hline & & $\begin{array}{l}\text { Types of methods of contractors' selection (tendering } \\
\text { method-open tendering, selective tendering, etc.) }\end{array}$ & [34] \\
\hline & & Work conditions & [34] \\
\hline & & Equal power/empowerment & [17] \\
\hline & & Well-structured and formal project approach & [33] \\
\hline & & Suitability of project management system & [17] \\
\hline & & Reasonability of project master and implementation plans & [33] \\
\hline
\end{tabular}


Table 2. Cont.

\begin{tabular}{|c|c|c|c|}
\hline Categories & Subcategories & Success Factors & References \\
\hline & & Dispute resolution process & [25] \\
\hline & \multirow{11}{*}{$\begin{array}{c}\text { Resource/Procurement- } \\
\text { Related Factors } \\
\text { (Labors, Materials, } \\
\text { Equipment and } \\
\text { Subcontractors) }\end{array}$} & Transparency in the procurement process & [34] \\
\hline & & Competitive procurement & [34] \\
\hline & & $\begin{array}{l}\text { Sufficient/good resource allocation (labor, materials, equipment } \\
\text { and subcontractors) }\end{array}$ & [35] \\
\hline & & Adequate funds/resources & [17] \\
\hline & & Extent of subcontracting & [34] \\
\hline & & Materials availability & [17] \\
\hline & & Equipment availability & [17] \\
\hline & & Skillful workers & [34] \\
\hline & & Escalation of material price influenced the success & [34] \\
\hline & & Insufficient supply of material influences & [34] \\
\hline & & Good performance from suppliers/subcontractors & [25] \\
\hline & \multirow{15}{*}{$\begin{array}{c}\text { Human } \\
\text { Capital-Related } \\
\text { Factors }\end{array}$} & Effective allocation of human resources & [33] \\
\hline & & Technical and professional capability & [17] \\
\hline & & Project manager's competency & [17] \\
\hline & & Project manager's experience & [17] \\
\hline & & Project team members' competency & [17] \\
\hline & & Project team members' experience & [17] \\
\hline & & $\begin{array}{l}\text { Project manager's ability } \\
\text { Existence of a sufficient team }\end{array}$ & $\begin{array}{c}{[17]} \\
{[33,35]}\end{array}$ \\
\hline & & Leadership skills & [17] \\
\hline & & Motivating skills & [17] \\
\hline & & Organizing skills & [17] \\
\hline & & Coordinating skills & [17] \\
\hline & & Team motivation & [17] \\
\hline & & Personnel issues & [17] \\
\hline & & Dedicated team & [34] \\
\hline & & PM commitment and involvement & [34] \\
\hline & \multirow{4}{*}{$\begin{array}{l}\text { Support (Financial, } \\
\text { HR, Security and Legal } \\
\text { and Administration) }\end{array}$} & Adequate financial support & [17] \\
\hline & & Adequate HR support & [17] \\
\hline & & Adequate legal and administration support & [17] \\
\hline & & Adequate security support & [17] \\
\hline & \multirow{8}{*}{$\begin{array}{l}\text { Stakeholder-Related } \\
\text { Factors (Client, } \\
\text { Consultant, Project } \\
\text { Manager and } \\
\text { End-Users) }\end{array}$} & Effective communication among project stakeholders & [34] \\
\hline & & Mutual trust among project stakeholders & [34] \\
\hline & & Strong commitment among project stakeholders & [34] \\
\hline & & Minimization of conflict between stakeholders & [34] \\
\hline & & Coordination among project participants & [34] \\
\hline & & Working relationships with other project stakeholders & [34] \\
\hline & & Clear understanding & [34] \\
\hline & & Stakeholder endorsement of project plans & [34] \\
\hline
\end{tabular}


Table 2. Cont.

\begin{tabular}{|c|c|c|c|}
\hline Categories & Subcategories & Success Factors & References \\
\hline & & Cooperation in solving problems among project stakeholders & [34] \\
\hline & & Cooperativeness of stakeholders on project & [47] \\
\hline & & Stakeholders' active participation & [34] \\
\hline & & Effective engagement from stakeholders & [34] \\
\hline & & Top management support from the client organization & {$[11,48]$} \\
\hline & & Client's confidence in the construction team & [34] \\
\hline & & $\begin{array}{l}\text { Client's experience of construction project organization and } \\
\text { management }\end{array}$ & {$[17,34]$} \\
\hline & & Client's responsiveness to the needs of the other stakeholders & [34] \\
\hline & & Client's active participation and commitment & [34] \\
\hline & & Client's responsiveness to the needs of the other stakeholders & [34] \\
\hline & & Client's management capability & [34] \\
\hline & & Client track record & {$[11,48]$} \\
\hline & & Project consultant's competence & {$[11,48]$} \\
\hline & & Project manager's ability & [17] \\
\hline & & Designer's ability & {$[11,48]$} \\
\hline & & Consultant's ability & {$[11,48]$} \\
\hline & & End-user's participation & {$[36,49,50]$} \\
\hline & \multirow{9}{*}{$\begin{array}{c}\text { Innovation, Learning } \\
\text { and Growth-Related } \\
\text { Factors }\end{array}$} & $\begin{array}{l}\text { Learning and use of past experience (learned from previous } \\
\text { projects) }\end{array}$ & {$[33,40,43,51]$} \\
\hline & & Adequate training & {$[33,36,40]$} \\
\hline & & Advanced technologies & {$[36,52,53]$} \\
\hline & & Advanced machinery & {$[36,52,53]$} \\
\hline & & Innovations & {$[36,52,53]$} \\
\hline & & Commitment to continuous improvement & [36] \\
\hline & & Level of automation in project & [36] \\
\hline & & Early and continuous involvement in the project development & [36] \\
\hline & & Adoption of innovative management approaches & [36] \\
\hline \multirow{13}{*}{$\begin{array}{l}\text { External Related } \\
\text { Factors }\end{array}$} & \multirow{13}{*}{$\begin{array}{l}\text { Country-Related } \\
\text { Factors }\end{array}$} & Effective government policies and regulations & [34] \\
\hline & & $\begin{array}{l}\text { Economic environment (stable economy and sound economic } \\
\text { policy) }\end{array}$ & [17] \\
\hline & & Political environment & [17] \\
\hline & & Physical environment & [17] \\
\hline & & Technological environment & [17] \\
\hline & & Legal environment & [17] \\
\hline & & Cultural environment & [17] \\
\hline & & Logical environment & [34] \\
\hline & & Social environment (public acceptance towards the project) & [17] \\
\hline & & Nature ecological environment (weather conditions) & [17] \\
\hline & & Bureaucratic interference & [34] \\
\hline & & Corruption & [34] \\
\hline & & Public opinion & [34] \\
\hline
\end{tabular}


Table 2. Cont.

\begin{tabular}{|c|c|c|c|}
\hline Categories & Subcategories & Success Factors & References \\
\hline & \multirow{5}{*}{$\begin{array}{c}\text { Construction } \\
\text { Industry-Related } \\
\text { Factors }\end{array}$} & Construction permits & [17] \\
\hline & & Construction regulations & [17] \\
\hline & & Construction laws, standards and codes & [17] \\
\hline & & Product and service certification & [17] \\
\hline & & Industry-related issues (availability of resources) & [34] \\
\hline
\end{tabular}

\subsection{Brainstorming Phase}

A brainstorming phase was conducted through 25 separate sessions over 10 weeks to adapt the 140 most important factors identified from the literature review that have an impact on construction project success.

The brainstorming questions were as follows:

1- What are we trying to achieve in this meeting?

2- What do you notice about the current factors affecting project success?

3- What concrete steps should we take to move forward?

4- Do you have any questions/notes about these factors?

5- What would you like to learn more about?

6- What additional information should we gather before we start?

7- What categories can we sort these ideas into?

8- How can we think about these factors from someone else's perspective?

9- What factors should we keep, modify, add or remove? Be specific.

The brainstorming participants were classified into five categories within the Egyptian construction industry. The primary category was contractors (construction companies), which represented $50 \%$ of the total. The second category was clients, which represented $15 \%$ of the total. The third category was consultants, which represented $10 \%$ of the total. The fourth category was project managers, which represented $12.5 \%$ of the total. The fifth category was project management experts, which represented $12.5 \%$ of the total. Figure 3 illustrates the quantity of every category.

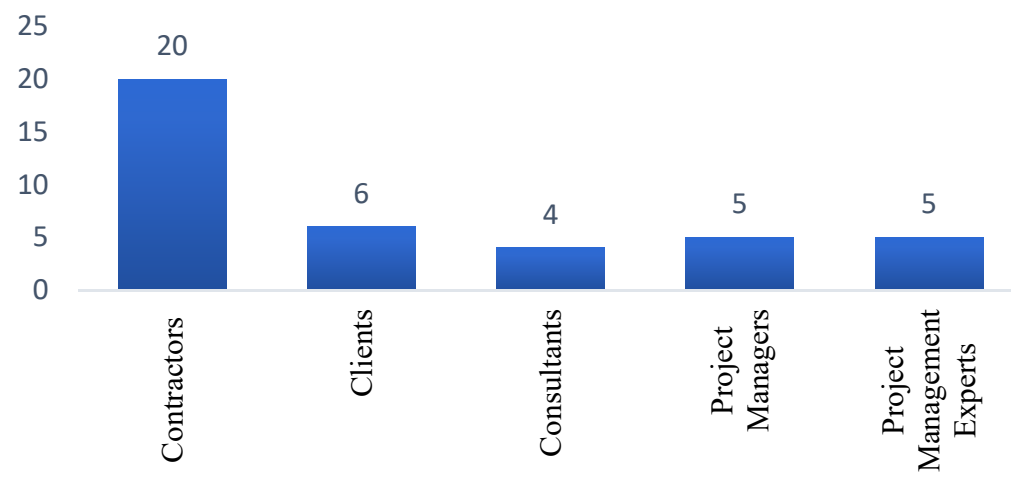

Figure 3. Classification of brainstorming participants.

After each session, the agreed results were collected, filtered and determined according to the number of repetitions. One hundred project success factors were classified into two main categories and their subcategories, as shown in Table 3, were identified as a result of this brainstorming exercise. 
Table 3. Summarized list of 100 factors affecting project success after brainstorming.

\begin{tabular}{|c|c|c|c|}
\hline Categories & Subcategories & ID. & Success Factors \\
\hline \multirow{37}{*}{$\begin{array}{l}\text { Internal } \\
\text { Related } \\
\text { Factors }\end{array}$} & \multirow{13}{*}{ Company-Related Factors } & F001 & $\begin{array}{l}\text { Availability of appropriate standards for leadership, organization, } \\
\text { structural and cultural aspects }\end{array}$ \\
\hline & & F002 & Availability of appropriate standards for tools, processes and metrics \\
\hline & & F003 & $\begin{array}{l}\text { Availability of a standardized information system for project } \\
\text { management }\end{array}$ \\
\hline & & F004 & Existence of appropriate ethical standards for projects \\
\hline & & F005 & $\begin{array}{l}\text { Appropriate clarification of the responsibility for problems related to } \\
\text { the project }\end{array}$ \\
\hline & & F006 & Company characteristics \\
\hline & & F007 & $\begin{array}{l}\text { The due separation between daily work activities and strategic } \\
\text { activities }\end{array}$ \\
\hline & & F008 & Delegation of authority and responsibility \\
\hline & & F009 & Standardization of decision-making process \\
\hline & & F010 & Company-wide acceptance (contractor) \\
\hline & & F011 & Contractor's competence and experience \\
\hline & & F012 & Company $\mathrm{E} \backslash$ economic and financial situation \\
\hline & & F013 & Top management commitment and support \\
\hline & \multirow{10}{*}{ Project-Related Factors } & F014 & Project type (new, existing, maintenance; public-private) \\
\hline & & F015 & Project value \\
\hline & & F016 & $\begin{array}{l}\text { Availability of project documents (drawings, specifications, contract } \\
\text { and bill of quantities) }\end{array}$ \\
\hline & & F017 & Well-defined scope of work and project constraints \\
\hline & & F018 & A clear description of project requirements, goals and objectives \\
\hline & & F019 & Complexity and uniqueness of the project \\
\hline & & F020 & The urgency of the project outcome \\
\hline & & F021 & Density of project \\
\hline & & F022 & A clear and detailed written contract \\
\hline & & F023 & Legal and contractual risk management \\
\hline & \multirow{14}{*}{$\begin{array}{l}\text { Project Management-Related } \\
\text { Factors }\end{array}$} & F024 & Planned profitability achievement \\
\hline & & F025 & Cash flow (in, out and net)—minimizing the cash deficit \\
\hline & & F026 & Achievement of the target work volume \\
\hline & & F027 & Project organization structure \\
\hline & & F028 & Achieving productivity \\
\hline & & F029 & Construction methods and constructability \\
\hline & & F030 & $\begin{array}{l}\text { Effective project time, cost, risk, quality resources, health and safety } \\
\text { planning, monitoring and control }\end{array}$ \\
\hline & & F031 & Effective troubleshooting and feedback \\
\hline & & F032 & Effective contract management \\
\hline & & F033 & Effective management of project changes and variations \\
\hline & & F034 & Effective collaboration, communication and information sharing \\
\hline & & F035 & Effective project performance management system \\
\hline & & F036 & Effective and timely conflict resolution \\
\hline & & F037 & Decision-making effectiveness \\
\hline
\end{tabular}


Table 3. Cont

\begin{tabular}{|c|c|c|c|}
\hline Categories & Subcategories & ID. & Success Factors \\
\hline & & F038 & Consider both opportunities and threats \\
\hline & & F039 & Obstacles and initiatives \\
\hline & & F040 & Supervision of subcontractors' works \\
\hline & & F041 & Site management and supervision \\
\hline & & F042 & Adequate budget availability \\
\hline & & F043 & Budget updates \\
\hline & & F044 & $\begin{array}{l}\text { Types of methods of contractors' selection (tendering method-open } \\
\text { tendering, selective tendering, etc.) }\end{array}$ \\
\hline & & F045 & Work conditions \\
\hline & & F046 & Equal power/empowerment \\
\hline & & F047 & Well-structured and formal project approach \\
\hline & & F048 & Suitability of project management system \\
\hline & & F049 & Reasonability of project master and implementation plans \\
\hline & & F050 & Dispute resolution process \\
\hline & \multirow{4}{*}{$\begin{array}{l}\text { Resource/Procurement- } \\
\text { Related Factors (Labors, } \\
\text { Materials, Equipment and } \\
\quad \text { Subcontractors) }\end{array}$} & F051 & Transparency in the procurement process and competitive procurement \\
\hline & & F052 & $\begin{array}{l}\text { Sufficient/effective resource allocation (labor, materials, equipment } \\
\text { and subcontractors) }\end{array}$ \\
\hline & & F053 & Escalation of material price influenced the success \\
\hline & & F054 & Good performance from suppliers/subcontractors \\
\hline & \multirow{7}{*}{$\begin{array}{l}\text { Human Capital-Related } \\
\text { Factors }\end{array}$} & F055 & Sufficient/effective allocation of human resources \\
\hline & & F056 & Technical and professional capability \\
\hline & & F057 & $\begin{array}{l}\text { Project manager's commitment, involvement, ability, competency and } \\
\text { experience }\end{array}$ \\
\hline & & F058 & Project team members' competency and experience \\
\hline & & F059 & Leadership, motivating, organizing and coordinating skills \\
\hline & & F060 & Personnel issues \\
\hline & & F061 & Dedicated team \\
\hline & \multirow{2}{*}{$\begin{array}{l}\text { Support (Financial, HR, } \\
\text { Security and Legal and } \\
\text { Administration) }\end{array}$} & F062 & Adequate financial support \\
\hline & & F063 & Adequate HR, security, legal and administration support \\
\hline & \multirow{10}{*}{$\begin{array}{l}\text { Stakeholder-Related Factors } \\
\text { (Client, Consultant, Project } \\
\text { Manager and End-Users) }\end{array}$} & F064 & $\begin{array}{l}\text { Effective working relationships, coordination, communication, mutual } \\
\text { trust, strong commitment among project stakeholders }\end{array}$ \\
\hline & & F065 & Minimization of conflict between stakeholders \\
\hline & & F066 & Clear understanding \\
\hline & & F067 & Stakeholder endorsement of project plans \\
\hline & & F068 & Cooperation in solving problems among project stakeholders \\
\hline & & F069 & Cooperativeness of stakeholders on project \\
\hline & & F070 & Stakeholders' active participation \\
\hline & & F071 & Effective engagement from stakeholders \\
\hline & & F072 & Top management support from the client organization \\
\hline & & F073 & $\begin{array}{l}\text { Client's management capability, confidence in the construction team, } \\
\text { the experience of the construction project and responsiveness to the } \\
\text { needs of the other stakeholders }\end{array}$ \\
\hline
\end{tabular}


Table 3. Cont.

\begin{tabular}{|c|c|c|c|}
\hline Categories & Subcategories & ID. & Success Factors \\
\hline & & F074 & Client track record \\
\hline & & F075 & Client's active participation and commitment \\
\hline & & F076 & Project manager's competence \\
\hline & & F077 & Designer's competence \\
\hline & & F078 & Consultant's competence \\
\hline & & F079 & End-user's participation \\
\hline & & F080 & Learning and use of past experience (learned from previous projects) \\
\hline & & F081 & Adequate training \\
\hline & & F082 & Advanced technologies \\
\hline & & F083 & Advanced machinery \\
\hline & Growth-Related Factors & F084 & Innovations \\
\hline & & F085 & Commitment to continuous improvement \\
\hline & & F086 & Level of automation in project \\
\hline & & F087 & Early and continuous involvement in the project development \\
\hline & & F088 & Adoption of innovative management approaches \\
\hline \multirow{12}{*}{$\begin{array}{l}\text { External } \\
\text { Related } \\
\text { Factors }\end{array}$} & \multirow{9}{*}{ Country-Related Factors } & F089 & Effective government policies and regulations \\
\hline & & F090 & $\begin{array}{l}\text { Economic, social (public acceptance towards the project) and } \\
\text { environmental }\end{array}$ \\
\hline & & F091 & Political and legal environment \\
\hline & & F092 & Physical, logical and cultural environment \\
\hline & & F093 & Technological environment \\
\hline & & F094 & Nature ecological environment (weather conditions) \\
\hline & & F095 & Bureaucratic interference \\
\hline & & F096 & Corruption \\
\hline & & F097 & Public opinion \\
\hline & \multirow{3}{*}{$\begin{array}{l}\text { Construction } \\
\text { Industry-Related Factors }\end{array}$} & F098 & Construction permits, regulations, laws, standards and codes \\
\hline & & F099 & Industry-related issues (availability of resources) \\
\hline & & F100 & Product and service certification \\
\hline
\end{tabular}

\subsection{Questionnaire}

Each respondent was required to provide numerical scoring for each factor expressing their opinions based on their experience in the Egyptian construction industry. The survey was created with the importance of each factor on project success in mind. Scores were divided into five categories: scores of 1 (extremely low impact), 2 (low impact), 3 (moderate impact), 4 (high impact) and 5 (extremely high impact).

\subsection{Data Collection}

\subsubsection{Determination of Required Sample Size}

To compute the specified sample size for an infinite population, we used the equation of Bartlett et al. [54] (1):

$$
N=K^{2} * P(1-P) / E^{2}
$$

where $N$ is the required sample size for an infinite population, $K$ is equal to 1.645 when the confidence level is $90 \%, P$ is the population proportion $-P$ is the degree of variation in 
the population's weather (the critical value of $P$ is 0.5 ) - and $E$ is an appropriate margin of error, at $10 \%$ for a confidence level of $90 \%$.

By substituting these parameters into Equation (1), the sample size for the infinite population in the specified study was 68 , which was the minimum value.

\subsubsection{Responses to the Questionnaire}

The data were gathered from a number of professionals and experts in Egypt's construction industry. Most were practicing contractors, clients, consultants, project managers and project management experts. The stratified system sampling technique was used for information collection.

A total of 150 questionnaires were distributed to Egyptian construction industry professionals and experts. In total, 90 questionnaires, representing $60 \%$ of all questionnaires administered, were returned. The return rate is shown in Table 4 .

\subsubsection{Classification of the Surveyed Experts Supported by Their Job Title Category}

It should be mentioned that the respondents' job titles were classified into five categories within the Egyptian construction industry. The primary category from the contractor's point of view represented $73.3 \%$. The second category from the client's point of view represented $7.7 \%$, the third category from the consultant's point of view represented $6.7 \%$, the fourth category from the project manager's point of view represented $5.6 \%$ and the fifth category from the project management expert's point of view represented $6.7 \%$, as shown in Figure 4.

Table 4. Details of questionnaires administered and the rate of return.

\begin{tabular}{cccc}
\hline $\begin{array}{c}\text { Construction Project Professionals and } \\
\text { Experts }\end{array}$ & $\begin{array}{c}\text { No. of Questionnaires } \\
\text { Distributed }\end{array}$ & $\begin{array}{c}\text { No. of Questionnaires } \\
\text { Returned }\end{array}$ & \% Rate of Return \\
\hline Contractors & 100 & 66 & 7 \\
\hline Clients & 12 & 6 & $50 \%$ \\
\hline Consultants & 12 & 5 & $41.6 \%$ \\
\hline Project Managers & 12 & 6 & $33.3 \%$ \\
\hline Project Management Experts & 14 & 90 & $64.3 \%$ \\
\hline Total & 150 & $60 \%$ \\
\hline
\end{tabular}

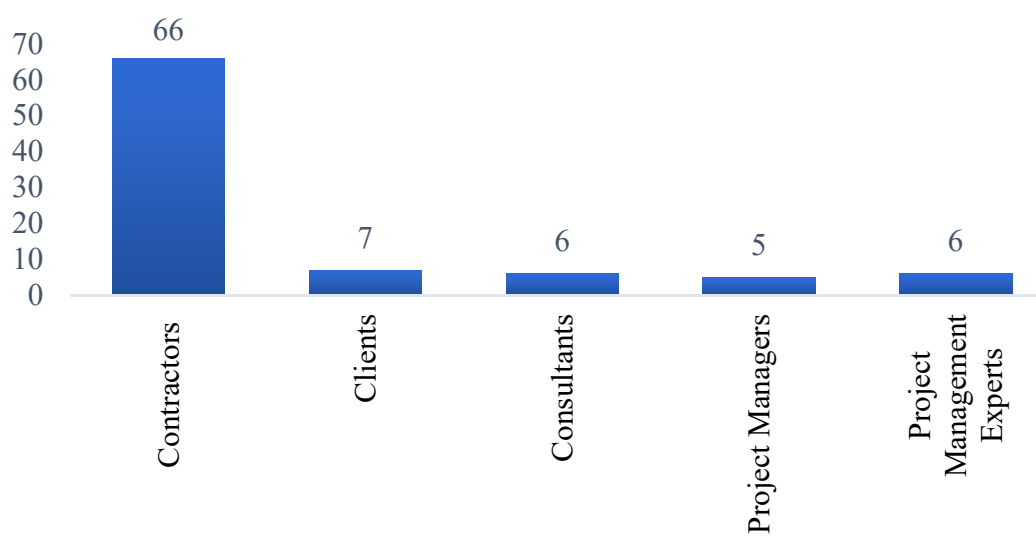

Figure 4. Classification and number of participating respondents based on their job title category.

\subsubsection{Classification of the Surveyed Experts Supported by Their Experience}

A survey of construction experts in Egypt's construction industry was conducted to identify the most important (critical) project success factors. The respondents to the questionnaire were classified in relation to their experience, as shown in Table 5. A more 
in-depth inspection of Table 5 clearly shows that about $56.7 \%$ of the respondents had an experience of greater than or equal to 20 years, around $33.3 \%$ had an experience of greater than or equal to 10 years and less than 20 years and, finally, $10 \%$ of respondents had an experience of less than 10 years.

Table 5. Classification of the surveyed experts based on their experience.

\begin{tabular}{ccccccc}
\hline $\begin{array}{c}\text { Years of Practicing in the } \\
\text { Construction Industry }\end{array}$ & Contractors & Clients & Consultants & $\begin{array}{c}\text { Project } \\
\text { Managers }\end{array}$ & $\begin{array}{c}\text { Project } \\
\text { Management } \\
\text { Experts }\end{array}$ & $\begin{array}{c}\text { Total } \\
\%\end{array}$ \\
\hline (Less than 10 years) & 5 & 1 & 1 & 1 & 1 & 20 \\
\hline $\begin{array}{c}\text { (Greater than or equal to 10 years } \\
\text { and less than 20 years) }\end{array}$ & 25 & 2 & 1 & 1 & 1 & 26 \\
\hline (Greater than or equal to 20 years) & 36 & 4 & 4 & 3 & 4 & 44 \\
\hline Total & 66 & 7 & 6 & 5 & 6 & $96.7 \%$ \\
\hline
\end{tabular}

\subsection{Data Analysis (Ranking of Project Success Factors Supported by Their Importance Index)}

Respondents to the questionnaire provided numerical scores expressing their opinions based on their experience working in Egypt's construction industry. Every factor was given a score by the respondents. This type of analysis entails a number of important steps, which can be summarized as follows:

First, the full score was calculated. Second, we calculated importance indexes for the previously identified 100 factors:

$$
\begin{aligned}
& \text { Total score }=\sum \text { score of each factor }=\sum_{i=1}^{n}(\mathbf{S}) \\
& \text { Importance Index }(\mathbf{I I})=\sum_{i=1}^{n}(\mathbf{S}) /\left(\mathrm{N}^{*} 5\right) * \mathbf{1 0 0}
\end{aligned}
$$

where $\mathbf{N}$ is the total number of people who responded to each factor $(\mathbf{N}=90)$ and the measurement's upper scale is represented by the number 5 . The relative weights of all categories and subcategories are shown in Figures 5 and 6.

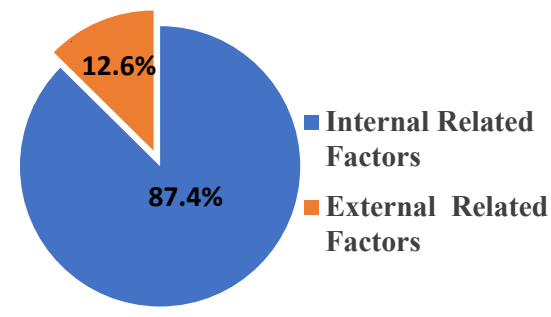

Figure 5. The relative weights of main categories.
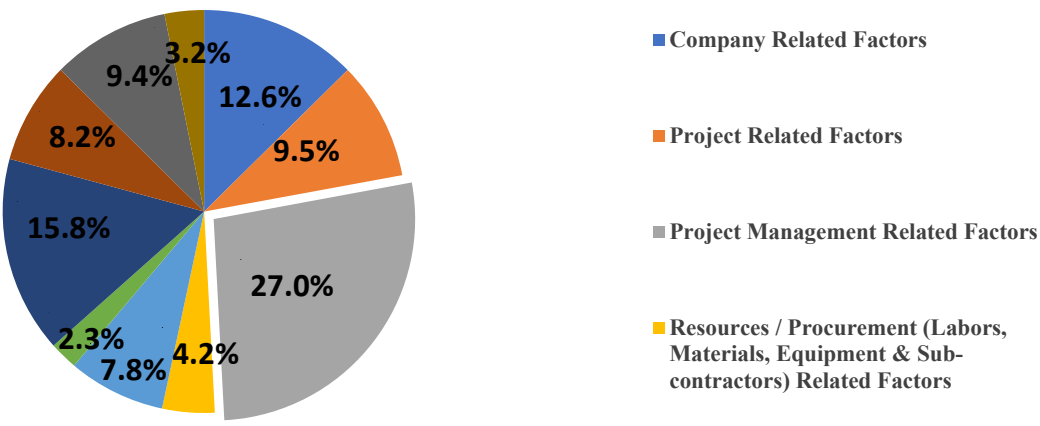

Figure 6. The relative weights of related factors-subcategories. 


\subsection{Most Important Factors}

Based on the analysis and review of the surveyed experts' opinions from the construction industry, factors with an average score above 4 (high impact on project success with an importance index greater than $80 \%$ ) represented the most significant project success factors as supported by a survey of construction consultants in Egypt using a questionnaire that aimed to determine the most important of all listed factors. Table 6 illustrates the ranking of the 40 factors that affect project success. They have an average score above 4 (high impact on project success with an importance index greater than $80 \%$ ). The most important 40 factors and their importance indices are as follows: achievement of planned profitability, 94.2\%; income (in, out and net)—reducing the cash deficit, 92.7\%; availability of project documents (drawings, specifications, contracts and bill of quantities), 92.0\%; sufficient/effective resources allocation (labor, materials, equipment and subcontractors), $90.0 \%$; achievement of the target work volume, $89.8 \%$; project organization structure, $88.9 \%$; achieving productivity, $88.4 \%$; construction methods and constructability, $88.0 \%$; company economic and financial situation, $87.6 \%$; effective project time, cost, risk, quality resources, health and safety planning, monitoring and control, 87.3\%; economic, social (public acceptance towards the project) and environmental, $87.1 \%$; effective government policies and regulations, $86.9 \%$; top management commitment and support, $86.7 \%$; project type (new, existing, maintenance; public-private), $86.2 \%$; sufficient/effective allocation of human resources, $86.0 \%$; effective working relationships, coordination, communication, mutual trust and strong commitment among project stakeholders, $85.8 \%$; effective troubleshooting and feedback, $85.6 \%$; technical and professional capability, $85.3 \%$; effective contract management, $85.1 \%$; adequate financial support, $84.9 \%$; project manager's commitment, involvement, ability, competency and knowledge, $84.7 \%$; construction permits, regulations, laws, standards and codes, $84.4 \%$; effective management of project changes and variations, $84.2 \%$; client's management capability, confidence in the construction team, the experience of the development project and responsiveness to the desires of the opposite stakeholders, $84.0 \%$; industry-related issues (availability of resources), $83.8 \%$; client's active participation and commitment, $83.6 \%$; effective collaboration, communication and knowledge sharing, $83.3 \%$; transparency within the procurement process and competitive procurement, $83.1 \%$; project team members' competency and skills, $82.9 \%$; project manager's competence, $82.7 \%$; designer's competence, $82.4 \%$; effective project performance management system, $82.2 \%$; consultant's competence, $82.0 \%$; project value, $81.8 \%$; obstacles and initiatives, $81.6 \%$; learning and use of past experience (learned from previous projects) $81.3 \%$, adequate budget availability $81.1 \%$, adequate HR, security, legal and administration support, $80.9 \%$; adequate training, $80.4 \%$; and leadership, motivating, organizing and coordinating skills, $80.2 \%$. These CSFs were identified by taking into consideration the three pillars of sustainability: (1) economic, represented by a company's economic and financial situation, project value, planned profitability achievement, cash flow (in, out and net; minimizing the cash deficit), achievement of the target work volume, effective project time, cost, risk, quality resources, health and safety planning, monitoring and control and adequate budget availability; (2) social, represented by all project stakeholders, i.e., client's management capabilities, consultant's competence, project manager's competence, construction industry and country regulations; and (3) environmental (minimizing the impact on the environment). Figure 7 shows the hierarchy of the project success categories, subcategories and the 40 most important factors affecting project success. 
Table 6. The 40 most important factors affecting project success.

\begin{tabular}{|c|c|c|c|c|c|c|c|}
\hline ID. & Success Factors & Categories & Subcategories & $\begin{array}{l}\text { Total } \\
\text { Score }\end{array}$ & $\begin{array}{l}\text { Average } \\
\text { Score }\end{array}$ & $\begin{array}{l}\text { Importance } \\
\text { Index }\end{array}$ & Rank \\
\hline F024 & Planned profitability achievement & Internal Related Factors & Project Management-Related Factors & 424 & 4.71 & $94.2 \%$ & 1 \\
\hline F025 & Cash flow (in, out and net)—minimizing the cash deficit & Internal Related Factors & Project Management-Related Factors & 417 & 4.63 & $92.7 \%$ & 2 \\
\hline F016 & $\begin{array}{l}\text { Availability of project documents (drawings, specifications, contract } \\
\text { and bill of quantities) }\end{array}$ & Internal Related Factors & Project-Related Factors & 414 & 4.60 & $92.0 \%$ & 3 \\
\hline F052 & $\begin{array}{c}\text { Sufficient/effective resources allocation (labors, materials, } \\
\text { equipment and subcontractors) }\end{array}$ & Internal Related Factors & $\begin{array}{l}\text { Resource/Procurement-Related Factors (Labor, } \\
\text { Materials, Equipment and Subcontractors) }\end{array}$ & 405 & 4.50 & $90.0 \%$ & 4 \\
\hline F026 & Achievement of the target work volume & Internal Related Factors & Project Management-Related Factors & 404 & 4.49 & $89.8 \%$ & 5 \\
\hline F027 & Project organization structure & Internal Related Factors & Project Management-Related Factors & 400 & 4.44 & $88.9 \%$ & 6 \\
\hline F028 & Achieving productivity & Internal related factors & Project Management-Related Factors & 398 & 4.42 & $88.4 \%$ & 7 \\
\hline F029 & Construction methods and constructability & Internal Related Factors & Project Management-Related Factors & 396 & 4.40 & $88.0 \%$ & 8 \\
\hline F012 & Company economic and financial situation & Internal Related Factors & Company-Related Factors & 394 & 4.38 & $87.6 \%$ & 9 \\
\hline F030 & $\begin{array}{l}\text { Effective project time, cost, risk, quality resources, health and safety } \\
\text { planning, monitoring and control }\end{array}$ & Internal Related Factors & Project Management-Related Factors & 393 & 4.37 & $87.3 \%$ & 10 \\
\hline F090 & $\begin{array}{l}\text { Economic, social (public acceptance towards the project) and } \\
\text { environmental }\end{array}$ & External Related Factors & Country-Related Factors & 392 & 4.36 & $87.1 \%$ & 11 \\
\hline F013 & Top management commitment and support & Internal Related Factors & Company-Related Factors & 390 & 4.33 & $86.7 \%$ & 13 \\
\hline F014 & Project type (new, existing, maintenance; public-private) & Internal Related Factors & Project-Related Factors & 388 & 4.31 & $86.2 \%$ & 14 \\
\hline F055 & Sufficient/effective allocation of human resources & Internal Related Factors & Human Capital-Related Factors & 387 & 4.30 & $86.0 \%$ & 15 \\
\hline F064 & $\begin{array}{l}\text { Effective working relationships, coordination, communication, } \\
\text { mutual trust, strong commitment among project stakeholders }\end{array}$ & Internal Related Factors & $\begin{array}{l}\text { Stakeholder-Related Factors (Client, } \\
\text { Consultant, Project Manager and End-Users) }\end{array}$ & 386 & 4.29 & $85.8 \%$ & 16 \\
\hline F031 & Effective troubleshooting and feedback & Internal Related Factors & Project Management-Related Factors & 385 & 4.28 & $85.6 \%$ & 17 \\
\hline F056 & Technical and professional capability & Internal Related Factors & Human Capital-Related Factors & 384 & 4.27 & $85.3 \%$ & 18 \\
\hline F032 & Effective contract management & Internal Related Factors & Project Management-Related Factors & 383 & 4.26 & $85.1 \%$ & 19 \\
\hline F062 & Adequate financial support & Internal Related Factors & $\begin{array}{l}\text { Support (Financial, HR, Security and Legal and } \\
\text { Administration) }\end{array}$ & 382 & 4.24 & $84.9 \%$ & 20 \\
\hline F057 & $\begin{array}{l}\text { Project manager's commitment, involvement, ability, competency } \\
\text { and experience }\end{array}$ & Internal Related Factors & Human Capital-Related Factors & 381 & 4.23 & $84.7 \%$ & 21 \\
\hline
\end{tabular}


Table 6. Cont.

\begin{tabular}{|c|c|c|c|c|c|c|c|}
\hline ID. & Success Factors & Categories & Subcategories & $\begin{array}{l}\text { Total } \\
\text { Score }\end{array}$ & $\begin{array}{l}\text { Average } \\
\text { Score }\end{array}$ & $\begin{array}{l}\text { Importance } \\
\text { Index }\end{array}$ & Rank \\
\hline F098 & Construction permits, regulations, laws, standards and codes & External Related Factors & Construction Industry-Related Factors & 380 & 4.22 & $84.4 \%$ & 22 \\
\hline F033 & Effective management of project changes and variations & Internal Related Factors & Project Management-Related Factors & 379 & 4.21 & $84.2 \%$ & 23 \\
\hline F073 & $\begin{array}{l}\text { Client's management capability, confidence in the construction } \\
\text { team, the experience of the construction project and responsiveness } \\
\text { to the needs of the other stakeholders }\end{array}$ & Internal Related Factors & $\begin{array}{l}\text { Stakeholder-Related Factors (Client, } \\
\text { Consultant, Project Manager and End-Users) }\end{array}$ & 378 & 4.20 & $84.0 \%$ & 24 \\
\hline F099 & Industry-related issues (availability of resources) & External Related Factors & Construction Industry-Related Factors & 377 & 4.19 & $83.8 \%$ & 25 \\
\hline F034 & Effective collaboration, communication and information sharing & Internal Related Factors & Project Management-Related Factors & 375 & 4.17 & $83.3 \%$ & 27 \\
\hline F051 & $\begin{array}{c}\text { Transparency in the procurement process and competitive } \\
\text { procurement }\end{array}$ & Internal Related Factors & $\begin{array}{l}\text { Resource/Procurement-Related Factors (Labor, } \\
\text { Materials, Equipment and Subcontractors) }\end{array}$ & 374 & 4.16 & $83.1 \%$ & 28 \\
\hline F058 & Project team members' competency and experience & Internal Related Factors & Human Capital-Related Factors & 373 & 4.14 & $82.9 \%$ & 29 \\
\hline F076 & Project manager's competence & Internal Related Factors & $\begin{array}{l}\text { Stakeholder-Related Factors (Client, } \\
\text { Consultant, Project Manager and End-Users) }\end{array}$ & 372 & 4.13 & $82.7 \%$ & 30 \\
\hline F077 & Designer's competence & Internal Related Factors & $\begin{array}{c}\text { Stakeholder-Related Factors (Client, } \\
\text { Consultant, Project Manager and End-Users) }\end{array}$ & 371 & 4.12 & $82.4 \%$ & 31 \\
\hline F035 & Effective project performance management system & Internal Related Factors & Project Management-Related Factors & 370 & 4.11 & $82.2 \%$ & 32 \\
\hline F078 & Consultant's competence & Internal Related Factors & $\begin{array}{l}\text { Stakeholder-Related Factors (Client, } \\
\text { Consultant, Project Manager and End-Users) }\end{array}$ & 369 & 4.10 & $82.0 \%$ & 33 \\
\hline F015 & Project value & Internal Related Factors & Project-Related Factors & 368 & 4.09 & $81.8 \%$ & 34 \\
\hline F039 & Obstacles and initiatives & Internal related factors & Project Management-Related Factors & 367 & 4.08 & $81.6 \%$ & 35 \\
\hline F080 & $\begin{array}{l}\begin{array}{l}\text { Learning and use of past experience (learned from previous } \\
\text { projects) }\end{array}\end{array}$ & Internal Related Factors & $\begin{array}{l}\text { Innovation, Learning and Growth-Related } \\
\text { Factors }\end{array}$ & 366 & 4.07 & $81.3 \%$ & 36 \\
\hline F042 & Adequate budget availability & Internal Related Factors & Project Management-Related Factors & 365 & 4.06 & $81.1 \%$ & 37 \\
\hline F063 & Adequate HR, security, legal and administration support & Internal Related Factors & $\begin{array}{l}\text { Support (Financial, HR, Security and Legal and } \\
\text { Administration) }\end{array}$ & 364 & 4.04 & $80.9 \%$ & 38 \\
\hline F081 & Adequate training & Internal related factors & $\begin{array}{l}\text { Innovation, Learning and Growth-Related } \\
\text { Factors }\end{array}$ & 362 & 4.02 & $80.4 \%$ & 39 \\
\hline F059 & Leadership, motivating, organizing, coordinating skills & Internal Related Factors & Human Capital-Related Factors & 361 & 4.01 & $80.2 \%$ & 40 \\
\hline
\end{tabular}




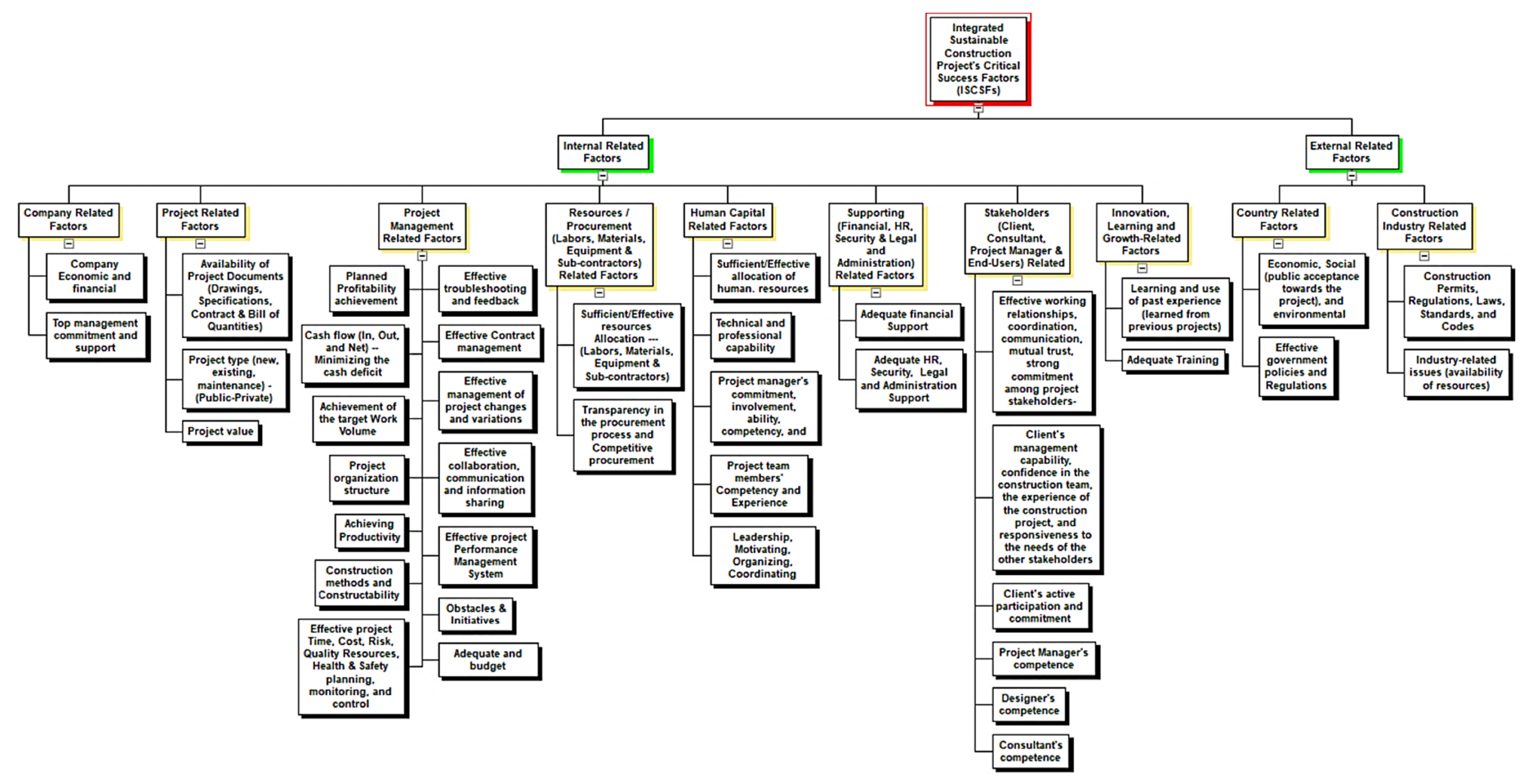

Figure 7. Hierarchy of project success categories, subcategories and the 40 most important factors affecting project success. 
Table 7 shows a summary list of the categories before and after the questionnaire results and ranking. It clearly illustrates that, instead of 88 factors, 36 factors only were considered within the internal related factors category, and for the category of factors associated with the external environment, the entire number of factors was decreased from 12 to 4 factors only. Figure 8 also reveals a comparison between the total number of factors in each category before and after the questionnaire results and ranking. Additionally, the load of every category is shown because the weights of internal related factors and factors associated with external were $90 \%$ and $10 \%$, respectively, as shown in Figure 9 . Thus, the main category (internal related factors) still has the maximum impact on the success of construction projects.

Table 7. Factors affecting project success before and after questionnaire results and ranking based on their categories.

\begin{tabular}{cccccc}
\hline \multirow{2}{*}{ No. } & Category & \multicolumn{2}{c}{$\begin{array}{c}\text { All Factors } \\
\text { before Questionnaire } \\
\text { Results and Ranking }\end{array}$} & \multicolumn{2}{c}{$\begin{array}{c}\text { Factors after } \\
\text { Questionnaire Results } \\
\text { and Ranking }\end{array}$} \\
\cline { 3 - 6 } & Sum & Weight & Sum & Weight \\
\hline 1 & Internal Related Factors & 88 & $88 \%$ & 36 & $90 \%$ \\
\hline 2 & External Related Factors & 12 & $12 \%$ & 4 & $10 \%$ \\
\hline & Total & 100 & $100 \%$ & 40 & $100 \%$ \\
\hline
\end{tabular}

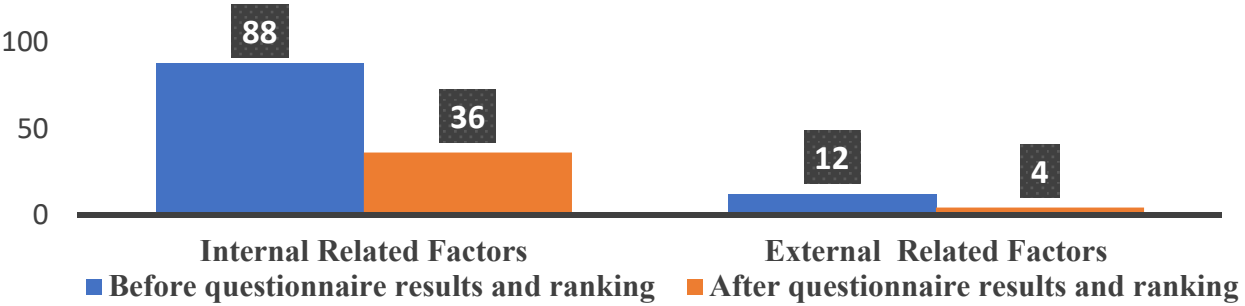

Figure 8. The total numbers of factors in the main categories before and after questionnaire results and ranking.

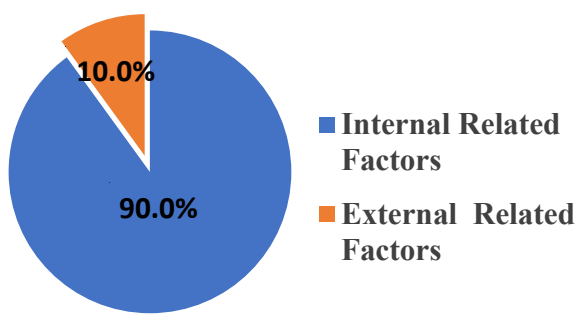

Figure 9. The relative weights of related factors in the main categories after questionnaire results and ranking.

Table 8 shows a summary list of subcategories before and after the questionnaire results and ranking. It clearly illustrates that only 2 factors instead of 13 were considered within the company-related factors category; 3 factors rather than 10 were considered within project-related factors; 14 factors rather than 27 were considered within project management-related factors; 2 factors rather than 4 were considered within resource-related factors; 5 factors rather than 7 were considered within human capital-related factors; 2 factors remained within support-related factors; 6 factors rather than 16 were considered within stakeholder-related factors; 2 factors rather than 9 were considered within innovation, learning and growth-related factors; and 2 factors rather than 9 were considered within 
country-related factors. For the category of factors associated with the housing industry, it was shown that the entire number of factors decreased from 3 to 2 factors only. Figure 10 also reveals a comparison between the total number of factors in each subcategory before and after the questionnaire results and ranking. Additionally, the load of every category is illustrated in Figure 11, showing that project management-related factors have the highest impact on project success (representing 35\%), followed by stakeholder-related factors (client, consultant, project manager and end-users) (representing 15\%), followed by human capital-related factors (representing $12.5 \%$ ), followed by project-related factors (representing $7.5 \%$ ). These were followed by company-related factors; resource/procurement-related factors (labor, materials, equipment and subcontractors); support (financial, HR, security, legal and administration); innovation, learning and growth-related factors; country-related factors; and construction industry-related factors (representing 5\%). Thus, the subcategory of project management-related factors still has the maximum impact on the success of construction projects.

Table 8. Factors affecting project success before and after questionnaire results and ranking based on their subcategories.

\begin{tabular}{|c|c|c|c|c|c|}
\hline \multirow[t]{2}{*}{ No. } & \multirow[t]{2}{*}{ Subcategory } & \multicolumn{2}{|c|}{$\begin{array}{c}\text { All Factors } \\
\text { before Questionnaire } \\
\text { Results and Ranking }\end{array}$} & \multicolumn{2}{|c|}{$\begin{array}{c}\text { Factors after } \\
\text { Questionnaire Results and } \\
\text { Ranking }\end{array}$} \\
\hline & & Sum & Weight & Sum & Weight \\
\hline 1 & Company-Related Factors & 13 & $13 \%$ & 2 & $5 \%$ \\
\hline 2 & Project-Related Factors & 10 & $10 \%$ & 3 & $7.5 \%$ \\
\hline 3 & Project Management-Related Factors & 27 & $27 \%$ & 14 & $35 \%$ \\
\hline 4 & $\begin{array}{l}\text { Resource/Procurement-Related Factors (Labors, } \\
\text { Materials, Equipment and Subcontractors) }\end{array}$ & 4 & $4 \%$ & 2 & $5 \%$ \\
\hline 5 & Human Capital-Related Factors & 7 & $7 \%$ & 5 & $12.5 \%$ \\
\hline 6 & $\begin{array}{c}\text { Support (Financial, HR, Security and Legal and } \\
\text { Administration) }\end{array}$ & 2 & $2 \%$ & 2 & $5 \%$ \\
\hline 7 & $\begin{array}{c}\text { Stakeholder-Related Factors (Client, Consultant, Project } \\
\text { Manager and End-Users) }\end{array}$ & 16 & $16 \%$ & 6 & $15 \%$ \\
\hline 8 & Innovation, Learning and Growth-Related Factors & 9 & $9 \%$ & 2 & $5 \%$ \\
\hline 9 & Country-Related Factors & 9 & $9 \%$ & 2 & $5 \%$ \\
\hline 10 & Construction Industry-Related Factors & 3 & $3 \%$ & 2 & $5 \%$ \\
\hline & Total & 100 & $100 \%$ & 40 & $100 \%$ \\
\hline
\end{tabular}

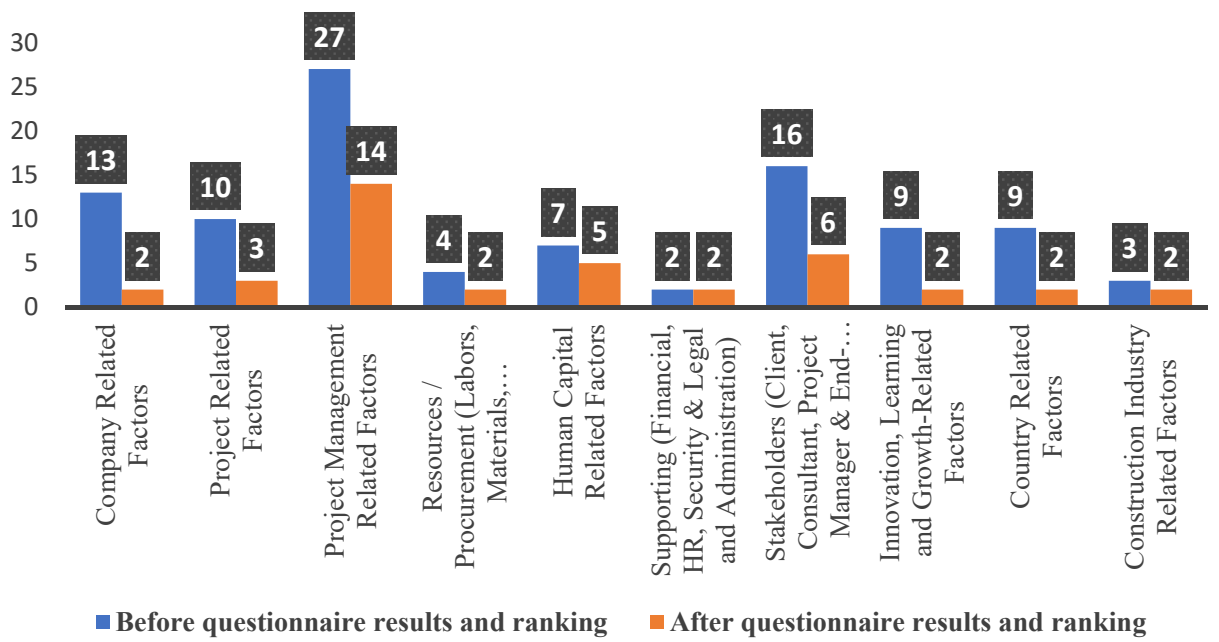

Figure 10. The total numbers of factors in subcategories before and after questionnaire results and ranking. 


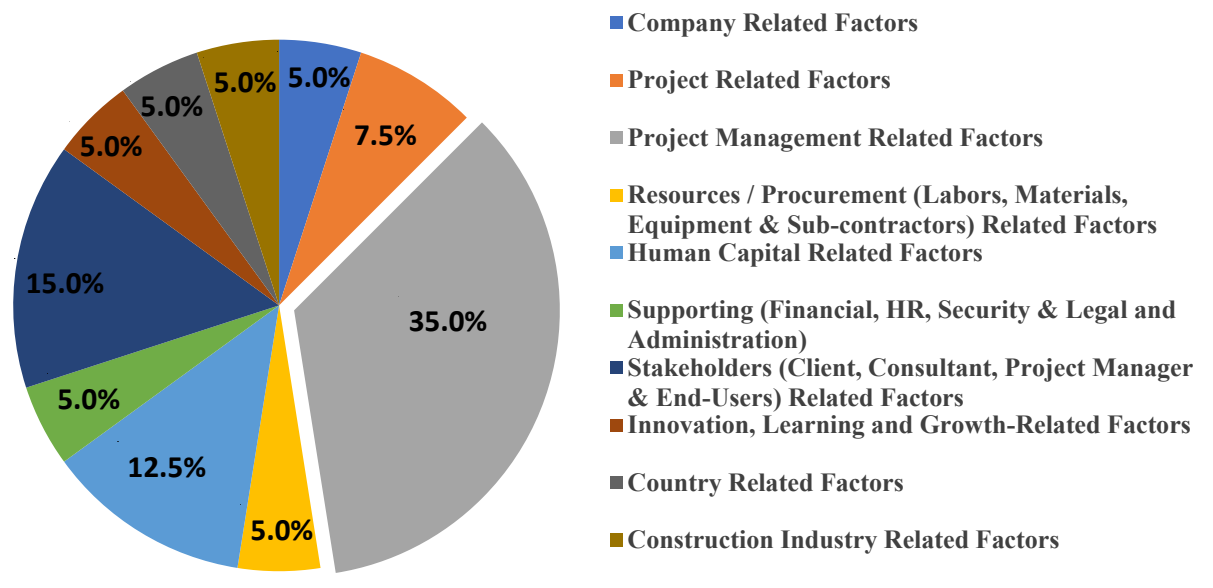

Figure 11. The weight of related factors in subcategories after questionnaire results and ranking.

Compared with previous studies, the project's success factors were identified in an integrated manner between all factors (internal and external) and taking into consideration the three pillars of sustainability (economic, social and environmental) where suitable for the Egyptian construction industry.

\section{Validation of Results}

The study's results were validated by the findings of specific group meetings through 10 separate individual sessions over 2 weeks. Basically, the perceptions of the specific group were in line with the study's results. The group agreed that achieving planned profitability and minimizing the cash deficit are the most important critical success factors affecting construction projects. Furthermore, it is necessary for the project's purpose, scale, scope and documents to be well defined to identify clients' predetermined needs and requirements. Additional factors were mentioned by the specific group: the client's financial capabilities and the client's satisfaction.

\section{Conclusions}

This study aimed to identify and prioritize the critical success factors (CSFs) that influence the performance of Egyptian construction projects in an integrated and sustainable manner. Critical success factors were identified and grouped into two major categories(1) internal related factors and (2) external related factors-and 10 subcategories-(1) company-related factors; (2) project-related factors; (3) project management related factors; (4) resource/procurement-related factors (labors, materials, equipment and subcontractors); (5) human capital-related factors; (6) support-related factors (financial, human resources, security and legal and administration); (7) stakeholder-related factors (clients, consultants, project managers and end-users); (8) innovation, learning and growth-related factors; (9) country-related factors; and (10) industry-related factors in three distinct stages. In total, 140 factors were gathered from the literature review in the first stage. In the second stage, a brainstorming session was conducted in order to reduce the number of those factors and focus on the most important factors that influence project success; thus, 100 factors were identified, filtered and developed. In the third stage, a questionnaire was created based on the significant factors identified. As a result, the 40 most important factors influencing the success of the performance of construction projects have been identified, which are integrated between all factors (internal and external) and take into account the three pillars of sustainability (economic, social and environmental) as a decision-making tool to evaluate and improve project performance. According to the number of factors for each subcategory, the results show that a project's success in the Egyptian construction industry depends mainly on project management-related factors, then stakeholder-related factors, then human capital-related factors, then project-related factors and finally the other 
remaining related factors (company; resources; support; innovation; learning; and growth, country and industry-related factors).

Based on the results of this study, the findings were considered in an integrated manner, taking into account the experience of all stakeholders in the Egyptian construction industry and their participation in the success of the project. In total, $73.3 \%$ of respondents belonged to the contractor group, which aims in future work to try to overcome these obstacles. This study did not consider the relative weights between categories, subcategories and factors. This can be investigated in future studies.

Author Contributions: Conceptualization, A.S.E.T., A.H.I. and H.H.M.; methodology, A.H.I. and H.H.M.; software, A.S.E.T.; validation, A.S.E.T., A.H.I. and H.H.M.; formal analysis, A.S.E.T.; investigation, A.S.E.T.; resources, A.H.I.; data curation, H.H.M.; writing—original draft preparation, A.S.E.T.; writing-review and editing, A.S.E.T., A.H.I. and H.H.M. All authors have read and agreed to the published version of the manuscript.

Funding: This research received no external funding.

Institutional Review Board Statement: Not applicable exclude this statement (the study did not involve humans or animals).

Informed Consent Statement: Not applicable exclude this statement (the study did not involve humans or animals).

Data Availability Statement: Not applicable exclude this statement (the study did not report any data).

Conflicts of Interest: The authors declare no conflict of interest.

\section{References}

1. Belassi, W.; Tukel, O.I. A new framework for determining critical success/failure factors in projects. Int. J. Proj. Manag. 1996, 14, 141-151. [CrossRef]

2. Cooke-Davies, T. Return of the project managers. Manag. Today 1990, 119. Available online: https://scholar.google.com/scholar? $\mathrm{hl}=$ en\&as_sdt=0\%2C5\&q=Cooke-Davies $\% 2 \mathrm{C}+\mathrm{T}+1990 \& b \operatorname{tnG}=\# \mathrm{~d}=\mathrm{gs}$ _cit\&u=\%2Fscholar\%3Fq\%3Dinfo\%3AX4RF75yUXuIJ\% 3Ascholar.google.com\%2F\%26output\%3Dcite\%26scirp\%3D0\%26hl\%3Den (accessed on 10 June 2021).

3. Müller, R.; Jugdev, K. Critical success factors in projects: Pinto, Slevin, and Prescott-the elucidation of project success. Int. J. Manag. Proj. Bus. 2012, 5, 757-775. [CrossRef]

4. Gudienè, N.; Banaitis, A.; Banaitienè, N.; Lopes, J. Development of a conceptual critical success factors model for construction projects: A case of Lithuania. Proc. Eng. 2013, 57, 392-397. [CrossRef]

5. Saqib, M.; Farooqui, R.U.; Lodi, S.H. Assessment of Critical Success Factors for Construction Projects in Pakistan. In Proceedings of the First International Conference on Construction Developing Countries (ICCIDC-1), Karachi, Pakistan, 4 August 2008.

6. Rubin, I.M.; Seelig, W. Experience as a factor in the selection and performance of project managers. IEEE Trans. Eng. Manag. 1967, 3, 131-135. [CrossRef]

7. Avots, I. Why does project management fail? Calif. Manag. Rev. 1969, 12, 77-82. [CrossRef]

8. Hughes, M.W. Why projects fail-the effects of ignoring the obvious. Ind. Eng. 1986, 18, 14.

9. Pinto, J.K.; Prescott, J.E. Planning and tactical factors in the project implementation process. J. Manag. Stud. 1990, 27, 305-327. [CrossRef]

10. Baker, B.N.; Murphy, D.C.; Fisher, D. Factors affecting project success. Proj. Manag. Handb. 1997, 902-919. [CrossRef]

11. Chua, D.K.H.; Kog, Y.C.; Loh, P.K. Critical success factors for different project objectives. J. Constr. Eng. Manag. 1999, 125, 142-150. [CrossRef]

12. Lim, C.S.; Mohamed, M.Z. Criteria of project success: An exploratory reexamination. Int. J. Proj. Manag. 1999, 17, $243-248$. [CrossRef]

13. Sadeh, A.; Dvir, D.; Shenhar, A. The role of contract type in the success of R\&D defense projects under increasing uncertainty. Proj. Manag. J. 2000, 31, 14-22.

14. Atkinson, R.; Crawford, L.; Ward, S. Fundamental uncertainties in projects and the scope of project management. Int. J. Proj. Manag. 2006, 24, 687-698. [CrossRef]

15. Patanakul, P.; Milosevic, D. The effectiveness in managing a group of multiple projects: Factors of influence and measurement criteria. Int. J. Proj. Manag. 2009, 27, 216-233. [CrossRef]

16. Khosravi, S.; Afshari, H. A success measurement model for construction projects. In Proceedings of the International Conference Financial Management Economic IPEDR, Hong Kong, China, 2-3 July 2011; IACSIT: Singapore, 2011; pp. 186-190.

17. Gudienè, N.; Banaitis, A.; Podvezko, V.; Banaitiene, N. Identification and evaluation of the critical success factors for construction projects in Lithuania: AHP approach. J. Civ. Eng. Manag. 2014, 20, 350-359. [CrossRef] 
18. Ihuah, P.W.; Kakulu, I.I.; Eaton, D. A review of critical project management success factors (CPMSF) for sustainable social housing in Nigeria. Int. J. Sustain. Built Environ. 2014, 3, 62-71. [CrossRef]

19. Osei-Kyei, R.; Chan, A.P. Implementing public-private partnership (PPP) policy for public construction projects in Ghana: Critical success factors and policy implications. Int. J. Constr. Manag. 2017, 17, 113-123. [CrossRef]

20. Molwus, J.J.; Erdogan, B.; Ogunlana, S. Using structural equation modelling (SEM) to understand the relationships among critical success factors (CSFs) for stakeholder management in construction. Eng. Constr. Archit. Manag. 2017, 24, 426-450. [CrossRef]

21. Banihashemi, S.; Hosseini, M.R.; Golizadeh, H.; Sankaran, S. Critical success factors (CSFs) for integration of sustainability into construction project management practices in developing countries. Int. J. Proj. Manag. 2017, 35, 1103-1119. [CrossRef]

22. Tripathi, K.K.; Jha, K.N. Application of fuzzy preference relation for evaluating success factors of construction organizations. Eng. Constr. Archit. Manag. 2018, 25, 758-779. [CrossRef]

23. Tripathi, K.K.; Jha, K.N. Determining Success Factors for a Construction Organization: A Structural Equation Modeling Approach. J. Manag. Eng. 2018, 34, 04017050. [CrossRef]

24. Maghsoodi, A.I.; Khalilzadeh, M. Identification and Evaluation of Construction Projects' Critical Success Factors Employing Fuzzy-TOPSIS Approach. KSCE J. Civ. Eng. 2018, 22, 1593-1605. [CrossRef]

25. Gunduz, M.; Almuajebh, M. Critical Success Factors for Sustainable Construction Project Management. Sustainability 2020, 12, 1990. [CrossRef]

26. Papulová, Z.; Gažová, A.; Šlenker, M.; Papula, J. Performance Measurement System: Implementation Process in SMEs. Sustainability 2021, 13, 4794. [CrossRef]

27. Liu, Z.-J.; Pypłacz, P.; Ermakova, M.; Konev, P. Sustainable Construction as a Competitive Advantage. Sustainability 2020, $12,5946$. [CrossRef]

28. Xiahou, X.; Tang, Y.; Yuan, J.; Chang, T.; Liu, P.; Li, Q. Evaluating Social Performance of Construction Projects: An Empirical Study. Sustainability 2018, 10, 2329. [CrossRef]

29. Milosevic, D.; Patanakul, P. Standardized project management may increase development projects success. Int. J. Proj. Manag. 2005, 23, 181-192. [CrossRef]

30. Gal, Y.; Hadas, E. Why projects fail: Knowledge worker and the reward effect. J. Knowl. Econ. 2015, 6, 968-977. [CrossRef]

31. Dinu, A.M. Project Risk Management-Reasons Why Projects Fail. Qual. Access Success Suppl. 2016, 17, 208.

32. Buys, A.J.; Stander, M.J. Linking projects to business strategy through project portfolio management. S. Afr. J. Ind. Eng. 2010, 21, 59-68. [CrossRef]

33. Paulo, S.F.; Oberti, A.; Valter, E.B.; Francisco, U.P. Critical Success Factors of Product Development Projects in the Automotive Industry. J. Technol. Manag. Innov. 2020, 15, 56-70.

34. Unegbu, H.C.O.; Yawas, D.S.; Dan-asabe, B. Structural Equation Model of the Relationship between Project Performance Measures and the Critical Success Factors of Construction Projects: A Case of the Nigerian Construction Industry. J. Mekan. 2020, $43,33-51$.

35. Frese, R.; Sauter, V. Project Success and Failure: What Is Success, What Is Failure, and How Can You Improve Your Odds for Success. 2003. Available online: http:/ / www.umsl.edu (accessed on 20 June 2019).

36. Peidong, S.; Haona, Y. Exploring Critical Success Factors for Green Housing Projects: An Empirical Survey of Urban Areas in China. Adv. Civ. Eng. 2019, 2019, 8746836.

37. Repenning, N.P. Understanding firefighting in new product development. J. Proj. Innov. Manag. 2001, 18, 285-300. [CrossRef]

38. Belout, A.; Gauvreau, C. Factors influencing project success: The impact of human resource management. Int. J. Proj. Manag. 2004, 22, 1-11. [CrossRef]

39. Yeo, K.T. Critical failure factors in information system projects. Int. J. Proj. Manag. 2002, 20, 241-246. [CrossRef]

40. Cooke-Davies, T. The "real" success factors on projects. Int. J. Proj. Manag. 2002, 20, 185-190. [CrossRef]

41. Poon, P.; Wagner, C. Critical success factors revisited: Success and failure cases of information systems for senior executives. Decis. Support Syst. 2001, 30, 393-418. [CrossRef]

42. Thite, M. Leadership styles in information technology projects. Int. J. Proj. Manag. 2000, 18, 235-241. [CrossRef]

43. Dvir, D.; Lipovetsky, S.; Shenhar, A.; Tishler, A. In search of project classification: A non-universal approach to project success factors. Res. Policy 1998, 27, 915-935. [CrossRef]

44. Cash, C.H.; Fox, R., II. Elements of successful project management. J. Syst. Manag. 1992, 43, 10.

45. Pozin, M.A.A.; Nawi, M.N.M.; Romle, A.R. Effectiveness of virtual team for improving communication breakdown in IBS project delivery process. Int. J. Supply Chain Manag. 2016, 5, 121-130.

46. Turner, J.R. Managing Web Projects: The Management of Large Projects and Programs for Web-Space Delivery; Gower Publishing, Ltd.: Aldershot, UK, 2004.

47. Stanley, R.; Uden, L. Why Projects Fail, from the Perspective of Service Science. In Proceedings of the 7th International Conference on Knowledge Management in Organizations: Service and Cloud Computing, Salamanca, Spain, 11-13 July 2012; Springer: Berlin/Heidelberg, Germany, 2013; pp. 421-429.

48. Asgari, M.; Kheyroddin, A.; Naderpour, H. Evaluation of Project Critical Success Factors for Key Construction Players and Objectives. Int. J. Eng. 2018, 31, 228-240.

49. Rasekh, H.; McCarthy, T.J. Delivering sustainable building projects—Challenges, reality and success. J. Green Build. 2016, 11, 143-161. [CrossRef] 
50. SinemKorkmaz, D.R.; Horman, M. Assessing project delivery for sustainable, high-performance buildings through mixed methods. Archit. Eng. Des. Manag. 2011, 7, 266-274.

51. Lindhard, S.; Larsen, J.K. Identifying the key process factors affecting project performance. Eng. Constr. Archit. Manag. 2016, 23, 657-673. [CrossRef]

52. Hwang, B.G.; Zhu, L.; Ming, J.T.T. Factors affecting productivity in green building construction projects: The case of Singapore. J. Manag. Eng. 2016, 33, 04016052. [CrossRef]

53. Lam, P.T.I.; Chan, E.H.W.; Poon, C.S.; Chau, C.K.; Chun, K.P. Factors affecting the implementation of green specifications in construction. J. Environ. Manag. 2010, 91, 654-661. [CrossRef]

54. Bartlett, J.E.; Kotrlik, J.W.; Higgins, C.C. Organizational Research: Determining Appropriate Sample Size in Survey Research. Inf. Technol. Learn. Perform. J. 2001, 19, 43-50. 